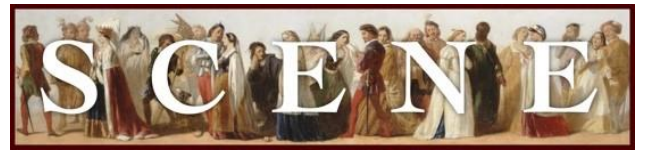

\title{
Review of Wellington Summer Shakespeare
}

\author{
by Kevin Quarmby. Written on 2017-10-15. Published in 2017 Issue 2.
}

David Lawrence, Wellington Summer Shakespeare 1983-2017 (Wellington: Victoria University Press, 2017). 128 pp. ISBN 1776560981, 9781776560981. http://vup.victoria.ac.nz/wellington-summer-shakespeare-1983-2017/

In COLLABORATION With WeLlington's Victoria University, THE SUMmER SHAKespeare Trust is celebrated in David Lawrence's lavishly illustrated book, Wellington Summer Shakespeare 1983-2017. Charting the birth and evolution of Wellington's self-proclaimed "only large-scale, large-cast, outdoor event," Lawrence's volume encapsulates over thirty years of drama club Shakespeare in New Zealand. Focusing chronologically on each annual summer offering, and incorporating archival reviews, first-hand evidence, and photographic record, the book explores the Summer Shakespeare experience of students and creatives who share a common goal of performing in the "cultural capital" of their nation (7).

In the book's "Prologue," Lawrence introduces this locally-grown student-oriented dramatic experience, whose "basic appeal" guaranteed the annual productions' survival, despite the vagaries of the Victoria University Drama Club malaise, closure, and subsequent financial limitations (7). Claiming to enjoy a "special allure in a city where professional theatres can seldom afford to stage" Shakespeare, and "must play it safe with small-scale productions of the well-known plays," Wellington's Summer Shakespeare offerings, so Lawrence describes, offer unique opportunities, especially to young New Zealand actors who could "play roles they might otherwise never get the chance to," free from the "economic constraints of professional theatre companies" who quash all Shakespeare completist risk-taking (7-8). In consequence, New Zealand audiences continue to enjoy plays as varied as Pericles, King John, and Cymbeline, with Lawrence gleefully referencing the 2015 production of Timon of Athens, the first such performance in New Zealand for 150 years (8).

Implicit in this historical foray into open-air New Zealand theater is an underlying politicization of the Summer Shakespeare experience. As Lawrence describes, between 1997 and 2000 the company productions were "nomadic," which also offered an opportunity to forge new relationships within the Wellington community (8). As if mirroring the beer-friendly environs of an original London playhouse, the company enjoyed seasons in a local vineyard as well as 
their more urban home (8). The most significant political impact, however, was what Lawrence describes as the "demise of a lot of extra-curricular student activities and organisations," which led to a twenty-first-century re-envisioning for the original student-centric Drama Club (now reinvented as the Summer Shakespeare Trust), and the appointment of its permanent administrator (8-9). Apart, therefore, from a hiatus in 2008, possibly indicative of the far larger global financial meltdown, Wellington audiences have enjoyed, and continue to enjoy, their Southern-hemisphere open-air February Shakespeare on an annual basis.

Interesting as it might be to New Zealand Shakespeare theater historians, Wellington Summer Shakespeare 1983-2017 might remain no more than a localized historical record were it not for certain anomalous choices in its publication. With three to four pages dedicated to each production staged since 1983, complete with cast and creative list, date and place of performance, and very precise detailing of the plays as theater constructs, a pattern of ephemerality emerges that is as fascinating as it is informative. As early productions of $A$ Midsummer Night's Dream (1983), Macbeth (1984), Twelfth Night (1985), and Romeo and Juliet (1986) confirm, the historical knowledge of these plays relies heavily on commentary gleaned from extant theater reviews to bring the performances to life (10-23). With Wellington newspapers like the Evening Post and the Dominion looming large in the text, we see the power and importance of contemporary review material as a reflection of the plays and their reception.

Lawrence's personal involvement with the Summer Shakespeare since 1993, and his eventual cochairing of the Trust between 2012 and 2016, brings even more to the historical narrative, as the productions under his tenureship are brought to life with the immediacy of reminiscence. Indeed, through Lawrence's description of his directorial decision-making for the $2009 \mathrm{Henry} V$ and 2010 Merry Wives, we are privy to an insider's view of the creative process and benefit far more from intimate, personal experience (97-105).

The shift exemplified in Lawrence's post-1993 insider view, from external review to internal first-hand observation, also highlights another fascinating aspect of theater ephemerality, brought to colorful life by the countless images accompanying each play. While the earliest productions rely heavily on archival photos of mixed quality and professionalism, with action shots often blurred by the technical limitations of the lighting and film stock available, a discernible shift from year to year offers a salutary lesson about visual records and their importance for academic research. The $2005 \mathrm{Much} A d o$, for example, relies almost entirely on near-professionally posed cast portraits that are aesthetically pleasing as photographic artifacts, but offer little by way of performance evidence (87-90). The same could be applied to the 2001 Cymbeline, the production photographs inviting our appreciation of the camerawielding skill of the image recorder, rather than informing our appreciation of the play (75-79). 
That live action photographs, rather than staged publicity shots, play a vital role as evidential support for the observations of review journalists and creative participants is highlighted by the record of the 2000 production of Love's Labor's Lost. Accompanying textual evidence from the play's director, Jonathon Hendry, Lawrence's book includes just one grainy black and white photo of a group of students smilingly promoting the company's show banner (73-74). Obviously intended as a newspaper publicity stunt, this photographic record offers even less than other photographic records in the book with which to reconstruct the performance or its stylistic choices. The play occurred, it was staged, and there the visual record ends. Lawrence's book demonstrates that photographers and visual materials were often neglected or forgotten because of the "complexities of archiving a theatre event that changes personnel every summer" (4).

Wellington Summer Shakespeare 1983-2017 is a significant addition to the New Zealand Shakespeare theater historical archive. Lawrence's informative and meticulously researched narrative guarantees that this specific example of open-air Shakespeare remains available to a broad audience, while also celebrating those students, professionals, and creatives who dedicated such time and energy to the event. As interesting, perhaps, to the discerning consumer of such books is the unwitting historical evidence that even a brief excursion into Wellington's Shakespearean theatrical past can uncover. In its documenting of the subtle nuances of political and social unrest, financial meltdown, or the status of review material and visual record, this book invites comparison with other localized evocations of Shakespeare on an international scale. 